Chapter Five

\title{
From World War to Cold War: Tvardovsky, Solzhenitsyn, Voinovich, and Heroism in the Post-Stalin Period
}

Life consists of more than just feats.

Жизнь же состоит не из одних подвигов.

-Vladimir Voinovich ${ }^{1}$

The science of laughing at ourselves is an unloved child among sciences: it's not in fashion now, not honored, as if only ordeals will follow ...

But meanwhile, to protect your honor, you can't find a better medicine.

Наука посмеяться над собой среди других наук-дитя дурное: она не в моде нынче, не в чести, как будто бы сулит одни мыстарства ... А между тем, чтоб честь свою спасти, не отыскать надежнее лекарства.

-Bulat Okudzhava ${ }^{2}$

In February 1946, less than a year after the Red Army had marched triumphantly into a defeated Germany, Stalin warned the populace that no relief was in sight: "As long as capitalism exists there will be wars, and the Soviet Union must be prepared."3 This was a prophecy, a prophecy that Stalin himself would help to fulfill.

Perhaps Stalin had learned of George Orwell's October 1945 newspaper essay entitled "You and the Atomic Bomb," in which he coined the phrase "cold war." Cold war was what Stalin described in his speech as he prepared Russians for an ongoing military and political struggle with the

1 Vladimir Voinovich, Interview with Konstantin Mil'chin, Russkii reporter, 14 April 2010, №14 (142), http://www.rusrep.ru/2010/14/interview_voynovich/.

2 "Vospitannym krovavoiu sud'boi," Zal ozhidaniia: stikhi (Nizhnii Novgorod: Izdatel'stvo Dekom, 1996), 24.

3 February 9, 1946. Quoted in Brown, Russian Literature since the Revolution, 226.

4 October 19, 1945, Tribune, London, Great Britain. 
West. War, as Randolph Bourne had observed in 1918, allows the state to emerge and exercise its control over the populace. The Cold War, which replaced the Second World War within a matter of months, created a permanent condition of wartime readiness: the arms race, the space race, the race to influence events in the developing and postcolonial world-these races shaped life on both sides of the iron curtain, and they ensured that the Soviet Union remained in a state of war through much of the twentieth century.

The Second World War ended with the atomic explosions over Hiroshima and Nagasaki. Four years later, the Soviet Union detonated its own nuclear weapon. Both events were cause for celebration and dread at the same time. To an extent that Bourne could never have imagined, the Cold War became the health of the Soviet state. ${ }^{5}$

The Cold War, therefore, became the unavoidable circumstance for all those who would write in its shadow, a noise in the background, which sometimes grew louder and sometimes faded but never went quiet. But the Cold War was not limited to East-West conflicts.

Immediately after the Second World War, as the Cold War was settling in, the concept of heroics began to change. War had promoted enterprising individuals and created camaraderie among soldiers. In the aftermath of war, soldiers struggled to hang on to either. The kind of solidarity that soldiers might feel after the war was vividly rendered in Boris Slutsky's unpublished poem "Night Conversations," in which veterans find a bit of comfort as they compare experiences in the darkness of a railway carriage, only to part when the train pulls into their station. The poem's narrator emphasizes the "rank and file" nature of the soldiers: "My humble comrade, / An ordinary enlisted man" ("Tovarishch moi negordyi, / Obychnyi, riadovoi"). War had brought these men together in common cause, but now they went their separate ways.

Postwar support for demobilized soldiers was uneven. Some returned home to shattered families, some had to contend with their own physical

5 On March 5, 2011, the fifty-eighth anniversary of Stalin's death, the Russian army newspaper Krasnaia zvezda carried an article claiming March 5, 1946, as the beginning of the Cold War. The article ends with the phrase, "In reality the cold war continues to this day, it's just that it has become less visible." See Natalia Yarmolik, "The Cold War Turns 65," http://www.redstar.ru/2011/03/05_03/3_02.html. Perhaps the Cold War is still the health of the Russian army. 
and psychological injuries, others were taken directly from the front lines into the prison camp system. Still others, like Slutsky's characters, found fellowship in anonymous encounters and then went on with their lives. As another of his poet-personas declares, "When we returned from the war, / I realized that we were not needed." 6

Both individualism and that sense of group solidarity posed potential threats to the Soviet system as World War II moved almost without interruption into the Cold War. Stalin needed to replace whatever "plastic juncture" the war might have created with a renewed control over the population. War, and the individual initiative that accompanies it, had in the past caused demands for internal reform in Russia. As historian Nina Tumarkin argues:

[In the past] wars had given those who had fought in them, especially junior officers, a sense of entitlement, of self-respect, of independence that inevitably led to demands for change. In Stalin's eyes, the wartime reliance on individual initiative was utterly incompatible with his continued or, rather, renewed totalitarian control of the country. The resurgence of the Stalinist apparat was his main domestic goal in the spring of 1945. (The Living and the Dead, 92)

The reconstruction of this apparat meant a glorification of the abstract at the expense of concrete soldier-heroes. ${ }^{7}$ Catherine Merridale has written about the construction of an "ideal soldier" who "took the place of all the diverse, the opinionated and self-confident fighters who came back from the front." As Hannah Arendt commented, in a "perfect totalitarian government ... all men have become One Man." After the war, the ideal hero was praised, but the actual veterans, who were individual human beings, could not find their place in society. ${ }^{8}$

6 Slutsky, "Bez popravok”..., 226.

7 Postwar, Tumarkin claims, "Self-sacrificial wartime heroes were rapidly demoted. This was no time to rest on one's laurels, much less to expect rewards. The only postwar hero was Hero Number One, and he was not inclined to make room for any competition. Military heroism per se faded from the novel, which moved its focus from feats of valor to the practical business of economic and social reconstruction" (The Living and the Dead, 100).

8 Merridale, Ivan's War, 385. Merridale considers Tyorkin to be part of the "Soviet Union's hero myth" and calls Tvardovsky's treatment of war "euphemistic" (Ivan's War, 6-7). I disagree. Hannah Arendt, "Ideology and Terror: A Novel Form of 
This chapter examines three writers and the postwar heroes they created within the context of the Cold War. We will look at what we might call the "posthumous" life of Tvardovsky's Vasily Tyorkin in the post-Stalinist era, as well as at a parody of the soldier's life story, Vladimir Voinovich's satirical and pointed Life and Adventures of the Soldier Ivan Chonkin, which couldn't be published in Russia until several decades after it was written. Between the two we find Solzhenitsyn's treatments of war and postwar life in his stories of the war and the Gulag. His Ivan Denisovich, a humble peasant-soldier akin to the one in Slutsky's poem, went straight from war to prison camp.

All three authors benefited from the patronage and personal endorsement of then-general secretary Nikita Sergeevich Khrushchev. Indeed, they wrote these works during Khrushchev's "thaw," and here an irony of semantics. The "thaw" initiated by Khrushchev, which permitted a certain level of cultural openness and allowed for a certain criticism of Stalinist excesses, occurred exactly when the Cold War became hardened and institutionalized. After all, between 1956 and 1964, Khrushchev presided over the suppression of the Hungarian Uprising, the launching of Sputnik, and the Cuban Missile Crisis (which most historians agree was the moment at which the world came closest to a nuclear exchange), and he pounded his shoe on the lectern of the United Nations, promising to "bury" the West. So without arguing the point too strenuously, we might suggest that the "thaw" amounted to replacing the terror of Stalinism with the terror of the Cold War and the threat of nuclear annihilation. The brief cultural thaw coexisted with a colder atmosphere in world politics than ever before. Russian writers must surely have seen that irony.

Soldiers in the post-Stalin era were no longer heroic. In the narratives of these three writers, soldier characters have survived the war to rejoin postwar society, whether they were "needed" or not, and they have lost their chance to be heroes. After all, a vital part of being a Soviet hero is death: from the moment Vasily Chapaev entered his watery grave, the death scene served to punctuate the hero's life in the mainstream Soviet narrative. In Soviet war novels, especially novels of World War II, it is virtually a rule that main heroes do not live to see the end of the book. In the 1970s this would again be the case: all five heroines in Boris Vasiliev's 1972 The Dawns Here Are Quiet per-

Government," in The American Intellectual Tradition, ed. David A. Hollinger and Charles Capper (New York: Oxford University Press, 2011), 340. 
ish, though in the two-reel film version of the book the viewer keeps hoping that at least one will survive.

This narrative phenomenon can be connected with a larger discourse about masculinity and nationalism, ${ }^{9}$ but it is also the case that once the early exemplary heroes had perished, other heroes were destined to follow suit. Chapaev's death set the agenda, and future war heroes tended to die as well. In contrast, during the Krushchev era we see soldiers who survive, including the nonheroic Chonkin. ${ }^{10}$

Each in their own way, Tvardovsky, Solzhenitsyn, and Voinovich rewrote the myth of the Soviet soldier in response to postwar life, when victory brought Cold War rather than peace.

\section{Tyorkin Lives}

There was nothing funny about the Second World War and its effect on the landscape and people of the Soviet Union, and yet Tvardovsky had created an amusing figure in his peasant-soldier character, and readers turned to Vasily Tyorkin for a laugh and a joke. Tyorkin was beloved in part because his adventures, his eternal cheerfulness, and the humor of his character made war into an everyday business, a daily task to be confronted with a positive attitude. Not didactic or ideological, Tyorkin's narrator presented the events of war as trying, difficult, but ultimately worth the effort. Tyorkin and his fellow soldiers believed they were fighting "for life on this earth"; readers too wanted to be convinced of that fact.

9 Karen Petrone does just this in her article "Masculinity and Heroism in Imperial and Soviet Military-Patriotic Cultures," in Russian Masculinities in History and Culture, ed. Barbara Evans Clements, Rebecca Friedman, and Dan Healey (New York: Palgrave 2002), 172-193. She specifically argues that "Military-heroic masculinity is intimately connected with modern nationalism, for to be a soldier-hero is to be willing to fight and die for one's nation" ("Masculinity and Heroism," 173). Petrone's argument traces the continuity with the imperial period, specifically the literature and cultural paradigms of the Russo-Japanese War, but also emphasizes that narrative patterns continued well into the Soviet period regardless of the fact that the "traditional model of individual heroism ... contradicted Soviet commitments to the value of the collective" ("Masculinity and Heroism," 175).

10 Voinovich's character draws his traits more from the folk character Ivan the Fool than from his fellow soldiers. In his review of Chonkin the year it was published, Geoffrey Hosking immediately connected the character with "Ivan-durak" (as well as with Jaroslav Hašek's Švejk). See "The Good Soldier Chonkin," Times Literary Supplement no. 3854 (23 January 1976): 93. 
By the end of Tvardovsky's book, the name Tyorkin had become an eponym. ${ }^{11}$ Just as Chapaev caught the imagination of Soviet readers and film buffs in the 1920s and 1930s, so too Tyorkin came to represent the peasantsoldier in World War II: inventive, creative, full of energy, and willing to die, if necessary, for his country. This kind of heroism both echoed what soldiers saw in their own regiments and gave them something to strive for, an attitude to emulate, a hero to admire.

According to the rules of the genre, an amusing poem with a picaresque hero should have ended with Tyorkin's triumph, perhaps even his marriage and the prospect of a happy family life. But this was wartime, and foregrounding goals of national and patriotic unity rather than genre conventions, Tvardovsky did not impose a cheerful conclusion onto his narrative. Instead, he left his hero's fate ambiguous; he admitted that he had to give up the idea of a plot, with its structure and conclusion, but instead "the genre of [his] work became not quite a chronicle, not quite a newsreel, but a 'book, a living, moving, free-form book, inseparable from the real business of the people's defense of the Motherland, of their feats in the war" ("Kak byl napisan," 265).

Tyorkin thrived in the campaigns of World War II. From the very outset, however, his author intended to leave Tyorkin—alive or dead-on the field of battle. He had no interest in writing about Tyorkin after the war. But after a decade of resisting readers' requests that he write a sequel, Tvardovsky did return to his hero in 1954. He used Tyorkin to delineate the new era of openness and cultural thaw, penning a new poem in a familiar meter, "Vasily Tyorkin in the Other World" ("Vasilii Tyorkin na tom svete"), that, as the author explained, took up from the chapter "Death and the Warrior," where Tyorkin, "left half-dead" on the battlefield, really might have ended up in the other world ("Kak byl napisan," 263 n. 3).

Initially rejected by censors, the new poem lay in Tvardovsky's desk drawer for the next nine years. In 1963, he found himself at a gathering of Soviet and Western writers at Nikita Khrushchev's Georgian dacha in Pitsunda, and Khrushchev requested that Tvardovsky read the anti-Stalinist

11 P. S. Vykhodtsev notes that the name became a "personification of the victorious people" when it began to be used as a password: "If you say Vasily Tyorkin gave it to you, / They'll let you through.” Vykhodtsev, "A.T. Tvardovskii i narodnaia khudozhestvennaia kul'tura (Vasilii Tyorkin)," in Tvorchestvo A.T. Tvardovskogo: issledovaniia $i$ materialy, ed. Vykhodtsev and N. A. Groznovaia (Leningrad: Nauka, 1989), 26-27. 
poem aloud. ${ }^{12}$ This was a satire on the "administrative-command system," and like all satires, it had to address the questions "against whom (or what) and in the name of what."13 Three days later, on August 18, 1963, the poem was published in Izvestiia as well as in the August issue of Novyi Mir. ${ }^{14}$ Tvardovsky used Tyorkin and Khrushchev ... and Khrushchev used Tyorkin and Tvardovsky. The enemy was Stalinism; the goal was cultural thaw and conversations about the past.

Tvardovsky would make the other world work for him.

\section{Tyorkin in the Other World}

When Tvardovsky returned to Tyorkin a second time, some readers were decidedly not amused. One critic wrote, "Tvardovsky did not have the right to turn to the hero of the Book about a Warrior again." ${ }^{15}$ Readers found the new Tyorkin to be too passive, too much of an observer. D. Starikov noted the change in tone in The Other World:

Submission to the inevitability of fate, spiritual depression, the feeling that one cannot come back to life-a motif almost completely missing before, in Vasily Tyorkin-prevails in Alexander Tvardovsky's new poem. Persistently, continually, and frankly utterly annoyingly, giving the entire narrative the flavor of no way out. (196)

No way out. Now that Tyorkin had come "back to life," readers found him depressing and annoying. Yet another reader put it this way:

In my opinion A. Tvardovsky violated his own authorial rights, if one can say it that way. Tyorkin personified an endless energy, optimism, resourcefulness. [...] In the new work the hero is placed-deliberatelyinto the artificial position of a resident of "the other world." [...] People will say to me: "You missed the point. This is a satire, a grotesque!" But

12 As Michael Scammell writes, the poem's "daring political content, as daring in its way as Ivan Denisovich, . . had condemned the poem to circulate underground ..." (Solzhenitsyn, 477) I rely on Scammell's account below.

13 For a recent comparison of "Tyorkin in the Other World" with the nineteenth-century satire of Saltykov-Shchedrin, see V. V. Prozorov, “Tyorkin na tom svete A.T. Tvardovskogo i shchedrinskaia satiricheskaia traditsiia," 105-119, in Do vostrebovaniia . . Izbrannye stat'i o literature i zhurnalistike (Saratov: Izdatel'stvo saratovskogo universiteta, 2010).

14 Below we will cite from "Terkin na tom svete," 377-404 in A. Tvardovskii and M. Gefter, XX vek: Gologrammy poeta i istorika (Moscow: Novyi Khronograf, 2005).

D. Starikov, “Terkin protiv Terkina," Oktiabr' 10 (1963): 196. 
for a grotesque, for a satire like this, our familiar and beloved Tyorkin is not appropriate. ${ }^{16}$

Instead of presenting a patriotic Book about a Warrior to do patriotic work, Tvardovsky used the character as a weapon to criticize current political conditions. Cranky readers missed the point. If in wartime Tyorkin had served to buoy up the common soldier and give him faith in the simple, clever Russian lads who were working together to save their fatherland, during the Thaw Tvardovsky wanted Tyorkin to serve another purpose entirely: to debunk some of the myths his character had participated in creating-for the sake of patriotic wartime rhetoric-and to highlight the horrors of the post-Stalinist Cold War bureaucracy.

Tvardovsky used Tyorkin as a Dante, a guide to an imaginary underworld, hoping to highlight problems in postwar Soviet life. In this underworld, Tvardovsky's hero meets with a fully bureaucratized society. His conversation with the general who greets him as he arrives clarifies for him that life in "the other world" is utterly hierarchical and leaves no room for individual endeavors. In a friendly tone, the general makes no bones about what awaits Tyorkin:

The General laughed:

All right. Go register.

There's a system, brother,

An order you need to know.

We welcome all comers,

Give each the place he deserves.

But who's a coward and who's a hero

Is not always clear and known.

There must be discipline, you know,

Discipline and order for all:

It's not that kind of war, brother,

Where each can fend for himself ...

(“Tyorkin na tom svete," 379)

16 N. A. Shlykunov. “Razve eto tot geroi?” Literaturnaia gazeta, 21 November 1963. Tvardovskii himself argued that the new poem was no "continuation" of the old, but a completely separate satirical work ("Kak byl napisan," 275, n. 4). The journal battle surrounding the publication was explored in V. and O. Tvardovskaia, "Istoriia odnoi fal'shivki: Epizod bor'by vokrug 'Terkina na tom svete,” Voprosy literatury 1 (2007): 36-52. 
The spatial geography of the underworld mirrors the militarized discipline of the Soviet state above, and Tyorkin makes his way through the halls of bureaucracy, finding them familiar-not that relative freedom of movement he had during the war, but rather the iron hierarchies of postwar Soviet life.

Tvardovsky piled up details using straightforward poetic lines, but the reader, along with Tyorkin, becomes more and more astonished at the ridiculousness of it all. Tyorkin passes the registration desk and finds himself at the "check-in desk," its own kind of bureaucratic hell, with its "shelves, safes, niches, drawers ... hefty books, folders, and card files."

And in the silence, like a dying breath

The words sound:

"Write down your auto-bio

Briefly and in detail...."

(“Tyorkin na tom svete," 380-381)

Both briefly and in detail... . Hell, it turns out, is just like life on earth, and all of the bureaucratic details of Soviet life are present, described as a parody of militarized order-the medical examination, the bedding distribution, even the editor's desk at the "Coffin Gazette." The only thing missing from this Soviet institution is the "complaint book" (kniga zhalob); in this "other world," good Soviet citizens have no complaints, or at least are not permitted to express them.

Tyorkin himself is called into question-after all, he's not really dead and should not be exploring the underworld. This too, though, is put down to his habit of not following the rules, not conforming, not fitting in with the collective. What in wartime was valued-individual initiative-is now denigrated:

However, he'll say, it's no wonder,

That you chose a wandering path.

Since you tore yourself asunder

From the collective-

There's the rub.

(“Tyorkin na tom svete," 386)

Upon meeting a friend, Tyorkin discovers that it's not merely the bureaucratic hurdles and the collectivist mores of Soviet society that are mirrored in 
the other world. Everything is the same, including the need for connections, as Tyorkin discovers when he gets sleepy and is looking for somewhere to bunk down, and his friend offers to use his connections to hook Tyorkin up.

It might seem that at least international political games would not pass beyond the border of death, but if Soviet ideology is present, capitalist ideology must be as well. As Tyorkin's friend explains, the Cold War is also being fought in the "other world"-indeed, as with life on earth, there are two "other worlds," separated by a version of the iron curtain:

You might not know, it's not visible.

There's the other world

Where you and I are,

And of course the bourgeois Other world.

Each of them has its own walls

With a shared ceiling

Two other worlds,

Two systems,

And a border with a lock.

Here and there-each with its rules

And, as it should be-

Everything is different, life and mores too....

(“Tyorkin na tom svete," 388)

Tyorkin is astonished, exclaiming, "How could it possibly matter after death?" ("Da ne vse li zdes' ravno?"), but the answer is expressed in an ideologically correct formula:

Here's the most important thing:

Our other world in the world beyond

Is the best and most progressive.

(“Tyorkin na tom svete," 389)

The fantastic setting of Tyorkin in the Other World permits Tvardovsky to use political clichés in his satire. Highlighting phrases from speeches and daily life ("best and most progressive," "our world," and "the bourgeois world"), the 
conversation approaches the Cold War competition between East and West as a normal status quo-even in the parallel world "below."

Tvardovsky did not stop with international politics, however; he turns his gaze on the Soviet Union itself. The narrator does not name names, but he doesn't have to. The many departments and desks that Tyorkin discovers include also a "special department," the leader of which is:

He who sent us

Into this processing plant.

In whose name you fell, soldier,

On the battlefield. [...]

The organizer of all fates, While still alive in the Kremlin

Organized a mausoleum

For himself along the way.

(“Tyorkin na tom svete," 395)

The unsentimental rendering of hell as a "processing plant" equates it with any large-scale industrial activity in the Soviet Union. Tvardovsky lays the blame for the militarized bureaucracy that only got more entrenched after the close of the Second World War squarely with Stalin himself. His "other world" features an exemplary military (which does its best to weed out the cowards), a highly developed bureaucracy, and, more importantly, the utter penetration of Stalinist values into daily life, including personal relationships. In fact, once Tyorkin's friend realizes that he is not really dead, he recognizes that he'll have to report him to "those who need to know" ("kuda nuzhno"). ${ }^{17}$

Stalinist values before the war had implied that class distinctions were at an end. ${ }^{18}$ Tyorkin's friend's experience in the "other world" belies that idea.

17 Tvardovskii, “Tyorkin na tom svete," 398. This reads almost as a preparody of Chonkin, whose entanglement with those "who need to know" is chronicled at the end of the first book of Chonkin and into the second book, where he has been arrested as a spy and deserter. See also E. G. Arzamastseva, “'Uzh ne parodiia li on?': K voprosu o sootnoshenii obrazov Vasiliia Tyorkina i Ivana Chonkina," in Literatura tret'ei volny, ed. V.P. Skobelev (Samara: Samarskii universitet, 1997), 123-132.

18 In his book Stalinist Values: The Cultural Norms of Soviet Modernity, 1917-1941, Hoffmann explores the ways in which the government promoted that sense of one classless, united society in the 1930 s. See especially chapter $5,146-183$. 
When the resurrected Tyorkin wants to bring his friend back with him to the "real" world, the friend has no desire to risk it:

Yes, but [back home] I might not end up

In the nomenklatura.

Today in the underworld I occupy

An important post.

And there, who am I today?

Should I toss my experience and rank to the dogs? ...

(“Tyorkin na tom svete," 400)

In contrast, the "other world" has no pull for Vasily Tyorkin. Rank- and classconsciousness, bureaucracy, reporting friends to the authorities-much of what was unpleasant in post-World War II Soviet Russia, and nothing at all to tempt Tyorkin to stay.

\section{For Life on this Earth}

The contrast between the sequel and the original Vasily Tyorkin measures the distance travelled from 1939 to the early 1960s. If Tyorkin and his comrades were willing to face all kinds of difficult situations during the war and felt a true comradeship in those days, when the word "comrade" really meant something, the postwar situation had deflated that patriotism. Life in either world was not particularly worth fighting for.

It was notable that in A Book about a Soldier, the wartime book about Tyorkin, the iconic character of political commissar familiar from Chapaev was missing. No one was telling Tyorkin what to do, and no one was looking over his shoulder. Even more importantly, perhaps, none of his comrades were reporting him to "those who needed to know." No betrayal, no complaints, just enemy fire, mined battlefields, dangerous river crossings, and strafing aircraft. There is, at one level, a purity and simplicity to a soldier's life during war. ${ }^{19}$ In the simplicity of combat, Vasily Tyorkin thrived.

Depicting life in Cold War Soviet society turned out to be more complicated.

19 As Walzer points out, it is a "great relief to follow orders" because it saves one from confronting any of the stickier moral and ethical questions about war (Walzer, Just and Unjust Wars, 311). 
In his notebooks from the 1960s, Tvardovsky noted the sensation of life's passage:

A third of my life has passed, and an important third at that-not that half-unconscious third of childhood and youth, nor that third remaining before me, but the most content-filled middle part. And it passed under the sign of war, first raging and burning day after day of its four years, and then hovering over my memory, over my consciousness and continuing to hover to this day-no matter what you're doing, no matter what you're thinking about, no matter what you're planning. Like that continual thought of death which some people-myself included-cannot escape. ${ }^{20}$

As Samuil Marshak wrote, these memories of the war include more than just horror; there is, after all, something good in them:

Anyone who has spent several years at the front and survived, both physically and morally, holds in his heart not only the memory of the dangers, the bitter losses and bad luck that war brings with it. He remembers something more as well: the intense feeling of a clearly acknowledged common goal, frontline friendships, comradely unity, that unity of feelings which he sorely misses later, in peacetime.

And at the very least, at the front a man is moving as one with his unit and thus he is at one with his time as well. ${ }^{21}$

In the postwar period, as mourning, hardship, and the difficulties of reconstruction were replaced by the fear and pressures of the Cold War, Soviet readers and writers held on to memories of the suffering and horrors of war and the triumph of victory. For Tvardovsky, the war was ever-present. But the postwar period brought terror and the Cold War, rather than peace, and Tvardovsky tried to take some responsibility for that as well. ${ }^{22}$

2024 June 1964, A. Tvardovskii, "Iz rabochikh tetradei 60-kh godov," quoted in A. Tvardovsky and M. Gefter, XX vek: Gologrammy poeta i istorika (Moscow: Novyi Khronograf, 2005), 372.

21 Marshak here explores an important idea for understanding Soviet life in wartime and beyond: for those who were willing to metaphorically "march in formation" in peacetime too, the transition was easier. But dissidents of any kind suffered before, during, and after the war. See Samuil Marshak, Radi zhizni na zemle: ob Aleksandre Tvardovskom (Moscow: Sovetskii pisatel', 1961), 63. See also discussion below of Joseph Brodsky's antipathy toward standardization and marching in formation.

22 "With his every line," Marshak wrote, "the poet announces that he too must take responsibility for the past." Marshak, Radi zhizni na zemle, 77. 
Tvardovsky believed that he was a part of history, and as such his poetry had to be more than just "a historical portrayal, a research paper, or an article; he is called upon as a contemporary, an involved witness." witness, to give testimony, meant that Tvardovsky had to continue to report what he saw after the war, the bad with the good. His readers may have been unhappy that he "resurrected" Tyorkin, tried to use the peasant-soldier hero to indict a postwar bureaucracy and sterility that undermined any sort of Soviet "victory" in the Second World War, but Tvardovsky raised themes of postwar life in an attempt to preserve relations among comrades, to preserve the dignity of Soviet life during the Cold War. Stalin's terror could not be ignored, and the hypocrisy and betrayal that had penetrated Soviet life had to be acknowledged as well.

\section{War and the Gulag}

By the late 1930s, two topics in Soviet history begin to overlap: Stalin's terror against his own citizens and the looming confrontation between the two reigning totalitarian systems, Soviet Socialism and Hitler's National Socialism. Out of terror and war came the militarized state, which was perpetuated further during the Cold War.

In literature, those topics became connected throughout the midcentury for several reasons. First of all, the experience of war in some cases was quite similar to the experience of labor camps: the individual lost all autonomy, was subjected to the rules and regulations of a hierarchical system, often in ill-fitting uniforms and in unsanitary, unheated living conditions, with inadequate food and medical care. War was like a labor camp, but "for the good of the cause," to use Vasily Grossman's title. Secondly, and perhaps more importantly, some of those who served in the war went directly from the front to the system of Soviet prison and labor camps, where they served sentences of ten years or more. For several decades after the war, literature about the Gulag could not be published. Discussion of prison camps was completely suppressed.

A final reason that literary works about the Gulag and the experience of war are intertwined in the Soviet context is Alexander Solzhenitsyn. It was the end of 1962 when Novyi Mir first published One Day in the Life of Ivan Denisovich (in November, \#11), a story in which the word zek, Russian slang

23 Marshak, Radi zhizni na zemle, 74 [emphasis here mine]. 
for "prisoner" or zakliuchennyi, made its debut on the printed page, and immediately afterwards Solzhenitsyn published the war story "Incident at Krechetovka Station" (January 1963, \#1, first excerpted in Pravda in December 1962). These two stories are both war stories, and both tell tales of betrayal. In a way, they represent two versions of the same story: both portray some Soviet soldiers following instructions in the militarized system and other soldiers arrested as spies, with no possibility of defending themselves.

As has been described many times, Tvardovsky was immensely excited when he received the manuscript submission of Shch-854 via editor Anna Berzer at Novyi Mir. ${ }^{24}$ There is no question that Tvardovsky saw the connection between the Second World War and the Gulag system; as he said somewhat euphemistically to Solzhenitsyn at one editorial meeting, "You show everyone both at the front and on the Siberian construction projects," i.e., in Soviet work camps.

Tvardovsky—and ultimately Khrushchev—loved Solzhenitsyn's manuscript in great part because the narrative was told from the point of view of a peasant, a simple, hard-working member of an agricultural kolkhoz who had served as a rank-and-file soldier during the war. As Kornei Chukovsky described the hero Ivan Denisovich in an unofficial review entitled "A Literary Miracle," "Shukhov was a generalized portrait of the Russian common man: resilient, stubborn, hardy, jack-of-all-trades, cunning, and kindhearted-close kin of Vasily Tyorkin." ${ }^{25}$ Rather than telling the story of labor camps from the point of view of a member of the intelligentsia, as Dostoevsky did in his Notes from the House of the Dead, Solzhenitsyn wanted the everyman view, and that view spoke plainly and clearly to both the peasanteditor Tvardovsky and the peasant-general secretary Khrushchev. Indeed, Khrushchev praised One Day in the Life of Ivan Denisovich to Tvardovsky as "a life-enhancing work that was fully in the spirit of the Twenty-Second Congress."

24 Scholars continue to speculate as to why this novella was published, rather than the work of Vasily Grossman, for example. The answers include, among others, the fact that Grossman wrote about a different set of prison camps, the Nazi camps at which Soviet POWs and European citizens, including Jews, were forced to work and/or put to death. The topic was discussed at the ASEEES Forty-second Annual Convention in Los Angeles in 2010, at the roundtable "Tolstoy and Grossman: Writing and Reading War and Peace in the Nineteenth and Twentieth Centuries." 
Interestingly, Solzhenitsyn's early war story, published just after One Day in the Life of Ivan Denisovich, made less of a splash. "Incident at Krechetovka Station" ("Sluchai na stantsii Krechetovka") ${ }^{26}$ takes place in 1941. The central character, Lieutenant Zotov, yearns to be sent to the front and chafes at his desk job at a train station, where he puts together trains to take troops, supplies, and so on to the various parts of the war zone. By 1962 the setting represents a retreat into the past, indeed, into the chaotic first year of the war about which Stalin and everyone else had maintained total silence for a decade and a half.

Scholars have suggested that in Lt. Vasily Zotov, "Solzhenitsyn portrayed, and satirized, his own younger self: puritanical, loyal, naive, idealistic, and fatally narrow in his blind devotion to the Soviet cause."27 Ivan Denisovich too is a patriot; he dreams of returning to his kolkhoz and can't imagine its present, he willingly completes the work required during his sentence, and he regrets the lost years but is resigned to his fate. Not perhaps as cheerful as Tyorkin, Shukhov is nonetheless a hard worker, inventive and crafty, if only in hiding his tools and husbanding his strength so that he can work better again the next day. He is certainly more sympathetic to the general Soviet reader, especially one like Khrushchev or Tvardovsky, than intellectual characters such as the Moscow Art Theater actor Tveritinov in "Krechetovka" or the filmmaker Tsezar Markovich portrayed in One Day.

"Incident at Krechetovka Station" focuses on Zotov's single-mindedness, as he-like Travkin in The Star-refuses the companionship of women, no matter how tempted he might be. Instead, Zotov is almost fatally seduced by another man, the misplaced passenger Tveritinov. Tveritinov is personally pleasant, easy to talk with, and the frustrated Zotov enjoys his company. But at this important juncture of the war, Zotov needs to figure out why Tveritinov is travelling alone, and at first he wants to believe the story Tveritinov spins about losing his regiment. He does not understand Tveritinov's hints at the year 1937; readers might think that the traveller is actually escaping

26 Solzhenitsyn's original title was "Incident at Kochetovka Station," the actual geographic location of the incident on which he based the story. However, because the editor of the right-wing journal Oktiabr' at the time was named Kochetov, Tvardovsky felt that the original title would cause unnecessary conclusions to be drawn about competition between himself and Kochetov, between Novyi Mir and Oktiabr'. Solzhenitsyn later restored his original title.

27 Scammell, Solzhenitsyn, 438. 
from a prison camp, but Zotov seems unaware that his guest might be a victim of Stalin's purges. ${ }^{28}$ Instead he decides that he is probably an imperialist spy. Tveritinov asks what Stalingrad used to be called, but it was renamed from Tsaritysn in Stalin's honor in 1925. Zotov reacts: "A Soviet person who doesn't know Stalingrad? That is utterly impossible! Utterly! Utterly!" (Rasskazy, 209). He decides that he has to report Tveritinov to "those who need to know."

The story deliberately leaves the reader, like Zotov, in uncertainty. In the wake of his decisive action, Zotov cannot find out whether Tveritinov was really a spy or whether he has sent the hapless soldier into the Gulag system; in horror, when he realizes that he's been reported, Tveritinov shouts to Zotov, "What are you doing? What are you doing? This cannot be corrected!!" (Rasskazy, 215). The reader too cannot decide: was Tveritinov a prevaricating White officer, sent to interrogate Zotov about train routes, front lines, and other military secrets? Or did Zotov doom a fellow Soviet citizen to captivity, torture, and death in a system where nothing can be "corrected," a system from which Tveritinov might have recently escaped?

Was there room in the Soviet system for the human warmth, the "instinctive liking" for Tveritinov which Zotov felt? (Rasskazy, 201). After all, Tveritinov could have been telling the truth; he could really have been an okruzhenets, a soldier who had briefly been encircled by the enemy but who had escaped back to his own. Trying to justify his snap decision, Zotov thinks to himself that "instructions required one to take especial care with the encircled, especially when they were alone" (Rasskazy, 200).

One of the harshest Soviet policies during World War II was the one regarding prisoners of war and other soldiers caught behind enemy lines. The fact that Kazakevich's characters in The Star perished during their reconnaissance duty kept them from the fates of many Soviet soldiers, including Solzhenitsyn's peasant character Ivan Denisovich.

Solzhenitsyn begins One Day in the Life of Ivan Denisovich at reveille, and already in the first paragraph there is no doubt as to its location: the barracks and even the reveille itself signal a military setting, but the guard, nadziratel', who is beating out the command and the two fingers' worth of frost on the windowpanes put us squarely in a Siberian prison camp.

28 Ivan Denisovich and his fellow prisoners talk openly about 1937 and 1938 and comment that a "special camp" allows for such conversation, since all the prisoners are politicals. See Alexander Solzhenitsyn, Rasskazy (Moscow: ACT, 2003), 59. 
The relationship between the militarized Gulag and the Red Army makes his imprisonment not that different for Ivan Shukhov, who is first and foremost a peasant-soldier. The narrator makes it clear that he was mobilized in the first days of the war: "Ivan Denisovich had left home on June 23, 1941." And he knew how to follow orders. Arrested before war's end, by the time of the novella's action, 1951, Shukhov remains in the power of his Soviet superiors. ${ }^{29}$

In the novel, each prisoner gets a backstory-how he ended up in the Gulag - and Ivan Denisovich's story ties his fate back to the war:

According to his dossier, Ivan Denisovich Shukhov had been sentenced for high treason. He had testified to it himself. Yes, he'd surrendered to the Germans with the intention of betraying his country and he'd returned from captivity to carry out a mission for German intelligence. What sort of mission neither Shukhov nor the interrogator could say. So it had been left at that-a mission.

Shukhov had figured it all out. If he didn't sign he'd be shot. If he signed he'd still get a chance to live. So he signed.

But what did Shukhov's confession really mean?

What really happened was this. In February 1942 their whole army was surrounded on the northwest front. No food was parachuted to them. There were no planes. [...] Their ammunition was gone. So the Germans rounded them up in the forest, a few at a time. Shukhov was in one of these groups, and remained in German captivity for a day or two. Then five of them managed to escape. They stole through the forest and marshes again, and, by a miracle, reached their own lines. A machine gunner shot two of them on the spot, a third died of his wounds, but two got through. Had they been wiser they'd have said they'd been wandering in the forest, and then nothing would have happened. But they told the truth: they said they were escaped POWs. [. . .] If all five of them had got through, their statements could have been found to tally and they might have been believed. But with two it was hopeless. (Rasskazy, 47; One Day, 55)

29 The Russian text of the novella can be found in Alexander Solzhenitsyn, Rasskazy (Moscow: AST, 2003), 7-116; English-language quotations come from One Day in the Life of Ivan Denisovich (New York: Signet Classic, 1998). 
This prisoner, who was in the army from the second day of the war, was able to continue his life in a militarized setting. "During his long years in prisons and camps hed lost the habit of planning for the next day, for a year ahead, for supporting his family. The authorities did his thinking for him about everything - it was somehow easier that way" (Rasskazy, 32; One Day, 35). Labelled a "spy," Ivan Denisovich remained a loyal soldier, obeying orders as much as possible, looking for shortcuts and ways to get what he needs (more food, warm clothing, tools for completing his work to his satisfaction). His position in the work squad resembled life in the regiment, which in turn resembles the ideal Soviet workplace, with each contributing according to his abilities. "Like a big family," Ivan Denisovich mused, "the work squad was a family" (Rasskazy, 58; One Day, 69).

Viktor Nekrasov, in a review that might have described Solzhenitsyn's work, remarked that official Soviet literature was, above all, "the most earnest literature in the world":

Earnest, because it concerns itself only with earnest matters-lifeaffirmation, optimism, enthusiasm, love of toil, and, most importantly, the formation of a new man. There is no room for jocularity here. Irony, anecdote, allusion and innuendo are not its weapons. Its weapon is of quite another steel, unbending, impenetrable and always shining; and the name of this weapon is socialist realism. ${ }^{30}$

Although Solzhenitsyn's topics eventually got him expelled from the Soviet Union-in particular because he chose to publish them, especially The Gulag Archipelago, abroad-his style fit right in with the prevailing Soviet formulae. ${ }^{31}$ These narratives consider soldiers in wartime and their postwar fates, and they suggest that loyalty to the state can have ambiguous consequences. The individual might find satisfaction in the daily tasks

30 Victor Nekrasov, “Being Earnest Isn’t Always Important," Survey 23.3 (104) (19771978): 42. The review was actually devoted to Venedikt Erofeev's Moskva-Petushki and Vladimir Voinovich's Ivankiada (1978).

31 Writers as varied as Voinovich and Vladimir Sorokin have expressed their annoyance at and/or concern with Solzhenitsyn's messianic stance after he went into exile. See Voinovich's parodic Moskva 2042 (Ann Arbor: Ardis, 1987) as well as his more serious Portret na fone mifa (Moscow: Eksmo, 2002). In Sorokin's novel Tridtsataia liubov' Mariny (Moscow: P. Elinin, 1995), the heroine-who is characterized by her random sexual encounters and dissident-worship-has a portrait of Solzhenitsyn in her apartment. 
of war or even of Socialist construction projects in a Siberian camp. But as in Cement, the novel about postwar reconstruction after the Civil War, the individual had to be sacrificed to the collective. These soldiers did their duty for the state, but there was no podvig in their attempts to negotiate the Stalinist system.

\section{The Hero as Parody: Chonkin}

As Nekrasov argued, there was no room in Soviet literature for irony, jocularity, or parody. But that does not mean that no one wrote in that vein. Ironically, or perhaps tellingly for the Thaw period, Nikita Khrushchev himself was instrumental in securing the initial fame of parodic writer Vladimir Voinovich. As memoirists describe it, the general secretary "couldn't resist" singing along with what was to become the "unofficial hymn to Soviet cosmonauts" as he presided from the heights of Lenin's mausoleum over the welcome parade for Yury Gagarin on Red Square in $1960 . .^{32}$

That song featured words by Voinovich, who would go on to publish a number of his early stories in Tvardovsky's journal Novyi Mir. In his lyrics for "Fourteen Minutes to Take Off" (“Chetyrnadtsat' minut do starta") Voinovich celebrated the great Cold War triumph of the Soviet Union: the space program. The lyrics have a colloquial tone and include disarming details. Rather than the rhetoric of podvig, the song uses byt: the cosmonauts talk about having a smoke before getting into their rocket, and though it seems like a countdown, it really isn't. After all, they have fourteen minutes until takeoff-not ten seconds.

The song's themes are innocuous, but they reinforce Soviet Cold War doctrine. The cosmonauts are portrayed as friends, comrades who are performing a task together. They trust their navigator, who will ensure that they succeed, making space travel a simple feat. In fact they cherish the earth, their home planet, but they will win the space race, thus also becoming the earth's eventual masters. This easy task parallels the success of World War II, and the cosmonauts recall Tyorkin, who always had a good meal and a smoke before going out to smash the enemy. In later redactions, to negate the light humor Voinovich inserted into his lyrics, the cosmonauts were to "sing" before departing rather than have a smoke.

32 Cornwell, "Voinovich," 880-882. 
Voinovich's early stories, straightforward, realistic narratives of life in the "virgin lands" and provincial villages, received accolades from important writers and critics such as Ehrenburg, Grossman, Marshak, Simonov, and Tendriakov. V. Kardin called Voinovich one of "the most talented young prose writers" of his time, and Tendriakov responded to Voinovich's first story, "We Live Here" (published in Novyi Mir in 1961), by exclaiming, "A fresh voice has appeared!"33

Herein lay the conflict of the Thaw period: while the new journal Yunost (Youth) was founded in 1955 and Soviet literature yearned for "new voices," those voices faced severe restrictions on what they could say. In the end, they also had to remain loyal to the Soviet state. Voinovich began publishing in Russia, but it soon became clear that his kind of voice, a satirical voice, was not welcome in his native land. To the best of his ability, Voinovich continued to participate in the literary life of his country, joining the Writers' Union in 1962 and assisting in the adaptation of his narratives for the stage, but at the same time, over the next decade his literary activity took another direction: writing petitions and protests to defend and support dissident writers and intellectuals like Andrei Sinyavsky, Yuly Daniel, Solzhenitsyn, and Andrei Sakharov. Eventually exiled and stripped of his citizenship in 1980, Voinovich and his family had to leave the Soviet Union to avoid internal exile or worse, and he remained in Germany until being invited back by Gorbachev some ten years later.

His best and most beloved work, The Life and Adventures of the Soldier Ivan Chonkin, was published as tamizdat in France in 1969. ${ }^{34}$ The novel comprises a parody of three genres: the folktale about Ivan the Fool, the saint's life, and the biographical novel about a heroic Soviet soldier. ${ }^{35}$ In-

33 L. B. Brusilovskaia, I. V. Konda, "Voinovich," in Russkie pisateli 20 veka: biograficheskii slovar', ed. P. A. Nikolaev (Moscow: Izd. Randevu-AM, 2000), 159; Tendriakov's review was published in Literaturnaia gazeta 25 (February 1961).

34 First published in Grani in 1969, possibly without the author's permission. An abridged version of the novel was published in Iunost', 1988 (12) and 1989 (1-2).

Originally planned as an "anecdote in five parts," Chonkin was the result of fifteen years of work for Voinovich throughout the 1960s and 1970s. Voinovich, Zhizn' $i$ neobychainye prikliucheniia soldata Ivana Chonkina (Paris: YMCA-Press, 1975) was followed by a second volume in 1979, Pretendent na prestol: novye prikliucheniia soldata Ivana Chonkina (Paris: YMCA-Press 1981). As one Russian bookselling Web site had it, in advertising the final volume of Chonkin's adventures: "Chonkin lived, Chonkin lives, Chonkin will live." Voinovich, Zhizn' i neobychainye prikliucheniia soldata Ivana Chonkina. Kniga III: Peremeshchennoe litso (Moscow: Eksmo, 2007). 
deed, Chonkin follows a decidedly non-heroic soldier, and in creating the character, Voinovich drew on the absurdist approach to chronicling war found in Jaroslav Hašek's 1923 The Good Soldier Švejk, part of what one critic has called "the tradition of anti-militarist satire." ${ }^{36}$ Even the author is inclined to exclaim, "What kind of an absurd figure is this?!!"-as Chonkin fulfills his duty to his fatherland in the days and weeks before the German attack on the Soviet Union by guarding a downed airplane in a Soviet village. The narrator puts these words into the readers' mouths, continuing in outrage, "Where is the example for [our] maturing youth?" In his own pseudo-defense, the narrator announces, "The hero of a book is like a child; you take what you get, you can't just throw him out the window. Maybe others have better children, smarter children, but your own is always more dear because it's yours." ${ }^{37}$

This parody of a soldier gives us an inside-out view of life in the Soviet military, with a hero the narrator himself calls defective. Unlike other World War II heroes, Chonkin does not die a heroic death, or indeed any death. He never even really serves, but sits out much of the war in the countryside. As Natalia Ivanova and Peter Vail commented in a Radio Free Europe broadcast in 2006, the very idea of parodic war literature may be commonplace in other national literatures (from Švejk to Joseph Heller's Catch-22, among many other examples), but in the Russian tradition Voinovich and his Chonkin stand alone. ${ }^{38}$

Voinovich had hoped to publish Chonkin in the Soviet Union, and editor of Novyi Mir Alexander Tvardovsky immediately recognized Chonkin's kinship with his own Tyorkin. As Voinovich recalled:

When I showed several chapters of Chonkin to Tvardovsky, he didn't like it, said that it wasn't funny or witty. Then he added that there were many such surnames: Travkin, Brovkin. ... He was silent for a minute, and then added: "Tyorkin. ..." I thought then that he might be right [...]: Travkins, Brovkins, Tyorkins, Chonkins. I went home and

36 Peter Petro, "Hasek, Voinovich, and the Tradition of Anti-Militarist Satire," Canadian Slavonic Papers XXII.1 (March 1980): 116-121.

37 Vladimir Voinovich, Zhizn'i neobychainye prikliucheniia soldata Ivana Chonkina (Moscow: Knizhnaia palata, 1990), 21. I will be citing from this edition of the novel.

38 Petr Vail', “Geroi vremeni," 16 January 2006. http://archive.svoboda.org/programs/ cicles/hero/21.asp. 
tried to change the surname. I wasted a lot of time, but nothing came of it. Chonkin remains Chonkin. ${ }^{39}$

Chonkin's function is reflective: he is the contemporary version of the satiric mirror that Gogol's mayor holds up to the audience in his 1842 comedy The Inspector-General. ${ }^{40}$ Voinovich recognized this difference:

He is neither Švejk nor Tyorkin. Švejk and Tyorkin are active heroes, Chonkin is passive. He stands where he was told to stand and he stands at his post until relieved. But he stands to the end, as a true soldier should. ${ }^{41}$

One critic explained that Private Chonkin's main problem (for the fictional Soviet reality in which he lived, and for his author, living in actual Soviet space) is that he has no prejudices, makes no assumptions, and simply encounters phenomena in life with an open mind and heart.

The thing is that every object, every phenomenon of everyday life is entangled with a multiplicity of connections and conditions, interwoven with invisible threads along with the conventional "rules of the game." But Chonkin is a natural man. He does not even suspect that these rules-required for all of us-exist. For him every object, every phenomenon exists, so to speak, in its primordial, pure state. And it only means what it means. ${ }^{42}$

In the novel, Voinovich uses various satirical devices to "expose the meaninglessness and mock the false grandeur" of the rhetoric of podvig. ${ }^{43} \mathrm{He}$ also employs estrangement, the technique Russian formalist theorists called

39 Voinovich, quoted in Vail', "Geroi vremeni."

40 On Gogol and Voinovich, see Victor Peppard, "Gogolian Substrata in Zhizn' $i$ neobychainye prikliucheniia soldata Ivana Chonkina," Russian Language Journal 38.131 (1984): 131-138.

41 Voinovich, “O sovremennosti i istorii," Rossiia/Russia 2 (1975): 233, quoted in Laura Beraha, "The Fixed Fool: Raising and Resisting Picaresque Mobility in Vladimir Voinovich's Chonkin Novels," SEEJ 40.3 (1996): 476.

42 Benedikt Sarnov, "Estestvennyi chelovek v neestestvennykh obstoiatel'stvakh. O geroe etoi knigi i ee avtore," 523-539 in Vladimir Voinovich, Zhizn'i neobychainye prikliucheniia soldata Ivana Chonkina (Moscow: Knizhnaia palata, 1990), 532.

43 See Khan, "Folklore and Fairytale Elements in Vladimir Voinovich's Novel The Life and Extraordinary Adventures of Private Ivan Chonkin," SEEJ 40.3 (1996): 494-518. 
ostranenie, in highlighting Chonkin's natural or naive way of perceiving the world around him. ${ }^{44}$ These literary devices aid Voinovich in deflating the very notion of the Soviet soldier. Everything from external situations-the uniform, language, and stance of a Soviet soldier-to internal inclinations undergoes transformation, as the false, inflated hero becomes a regular guy. Chonkin approaches his military service as he would normal life, and Voinovich chronicles his desires to sleep, have sex, and be comfortable in his surroundings-in other words, to live his life as best he can under the circumstances.

Orphaned early in life, Chonkin lost his foster parents as well. He is only semi-educated and tries to approach his military and political training humbly. These characteristics follow genre conventions for two Russian genres, the hagiographic story and the fairy tale. Halimur Khan argues that in a fairy tale, there are two possible kinds of heroes, victim-heroes and seeker-heroes. "Victim-heroes like Chonkin," he maintains, "begin their journey, or better even, their wanderings, without any particular goal in mind. Adventures thus await the victim-hero. He is the passive recipient of action." ${ }^{45}$

Chonkin is chosen to guard the downed aircraft (truly a valuable piece of state property) precisely because of his passive nature. He can be trusted not to act in any way, not to try and repair the plane, or sell it for parts, or in any way interfere with it. He is passivity personified, and his superiors depend on that, even when they have already forgotten about him entirely. Voinovich had intended to have Chonkin "stand at guard" until removed, indeed, until the end of the war, somehow "victorious over everyone" despite his total passivity. ${ }^{46}$ Not bravery plus consciousness; in fact not brave and not conscious, just fulfilling his duty to the state without asking any questions.

\section{Chonkin: A Real Man?}

While Chonkin is a comedic figure on his own terms, the parody here refers more specifically to another famous story that centers around a plane. The hero of Boris Polevoi's Stalin-prizewinning 1947 novel The Story of a

44 Sarnov points out that Voinovich (in a story about the Great Leader of the Peoples) describes Stalin's house as standing "behind the high red brick fence that is known the world around. To call the steeped in legend 'walls of the ancient Kremlin' simply $a$ fence-Lord almighty, this wouldn't occur to everyone," 535.

45 Khan, "Folklore," 512.

46 Voinovich quoted in Vail', "Geroi vremeni." 
Real Man (Povest' o nastoiashchem cheloveke) takes off on an unauthorized mission and crashes his plane in enemy territory. This novel, based on the biography of Alexei Maresiev, became emblematic of the Soviet heroic feat in wartime. ${ }^{47}$ The popular 1948 film The Story of a Real Man (directed by Alexander Stolper) cemented the image of the legless aviator in the Soviet imagination..$^{48}$

The narrative weight of Polevoi's story falls on the hero's long and arduous crawl back to Soviet lines. Seriously wounded, legs and arms broken, without food or water, the hero-seeker drags his body for days on end in quest of his comrade soldiers. Readers of the narrative might ask, however, about the plane: this airman has destroyed not only his body but also a major piece of needed technology in a foolish, unnecessary run based on unreliable information.

Perhaps, however, the heroic struggle to survive was not what made Meresiev a real man; the second half of the narrative features a political commissar, also seriously wounded, who gives Meresiev the strength and motivation to stand up on his artificial legs and get back into a plane to fight the enemy. The transformation into a "real man" comes when Meresiev returns to the skies to continue to shoot down German planes.

Ivan Chonkin had no political commissar. His daftness at political meetings kept any well-meaning commissar from being able to influence his behavior. Voinovich deliberately undercuts any "positive" Soviet meaning that might be implied in his story. While Chonkin does not benefit from the advice and mentoring of a commissar figure, as Meresiev and Chapaev did, Voinovich does pair him with what Laura Beraha identifies as part of another traditional twosome: "the fool and the false pedant, part of the dialogical interanimating effect of foolish non-comprehension, the calling into question of power-based, established and thus moribund truths." ${ }^{49}$ Chonkin's neighbor Gladyshev, in a parody of Soviet genetics, is attempting to create a hybrid tomato-potato plant so that in the most perfect of future societies, both the roots and the branches will bear fruit. Gladyshev's other experiments (which

47 Polevoi named his character Aleksei Meres'ev.

48 The film was seen by 34.4 million viewers and, like the novel, received a Stalin Prize (Youngblood, "Russian War Films," 92). The real pilot claimed never to have read the book or seen the movie; he lived the life of a "legend," dying only in 2001. For what must have been virtually his last interview, see Igor' Izgarshev, "Aleksei Mares'ev: Ia chelovek, a ne legenda!” Argumenty i fakty no. 19 (1072) (8 May 2001). 
include creating vodka from fecal matter) point to the essentially sophomoric nature of this character and his role in the novel; if Chonkin is looking for knowledge and enlightenment, he won't find it next door. ${ }^{50}$

But writing about a hero (in the style of a saint's life) and fecal matter also pushes the genre possibilities in ways that are important to Voinovich. As the author explained in an autobiographical note:

One should keep in mind that I am a satirist. A satirist differs from writers working in other genres in that he concentrates his attention on the shady sides of life and on negative tendencies. More than others he emphasizes existing problems and even goes overboard. Without this there cannot be any satire. ${ }^{51}$

This kind of "overemphasis" was not welcomed in the late 1960s any more than it would have been in the early 1950s. When in 1952 Stalin pronounced, "We need our Gogols and Shchedrins," authors of the day knew that this call for critique and criticism, satire and savagery, was not authentic.

In the post-Stalin period, there was a little more wiggle room for satire, but not much. After Khrushchev was removed by political coup, the endorsement by the general secretary could no longer help Voinovich or Tvardovsky. Voinovich himself was "removed" from literary life, and even from "Fourteen Minutes to Take Off," which began to be performed without words- that is to say, without Voinovich's text. The author was expunged from his own popular patriotic song, and eventually from the Soviet Union, following the dissident Solzhenitsyn into exile. It may be that satire-like samizdat and tamizdatwas a medicine too bitter for the Soviet system to tolerate.

Cultural thaw in the early 1960s led to the publication of new authors like Voinovich, to new explorations with old characters-like Tvardovsky's expedition into the "other world" with his Tyorkin—and to new themes, such as

50 Petro points to the "excremental" connection between Hasek's novel and Voinovich's, referencing Norman O. Brown, “The Excremental Vision," in Life against Death: The Psychoanalytical Meaning of History (Middleton, Conn.: Wesleyan University Press, 1959), 186-201. See Petro, “Hasek, Voinovich," 119.

51 Qtd. in Sarnov, “Estestvennyi chelovek," 535. 
Solzhenitsyn's exposés of wartime tattlers and post-war victims, including his peasant-soldier, sent to the Gulag. Khrushchev's cultural thaw ended when he was ousted and replaced by Leonid Brezhnev in 1964, but Cold War politics and internal persecution continued throughout the seventies and most of the eighties.

One tactic of the Brezhnev administration to try and create a social cohesion was to refocus the nation's attention on World War II. All publication of war memoirs was transferred to the Military Publishing House and subjected to strict censorial control. It was at this time-1965, the twentieth anniversary of the end of the war-that Victory Day became a national holiday and the cult of World War II began to grow..$^{52}$

Literary critic and war veteran Lazar Lazarev recalled:

Those of us who had fought in the war thought, at first, that at last the war was getting the attention it merited. But in fact that attention was purely an official attempt to turn the war into a show made up of concocted legends. ${ }^{53}$

In this new world, the old heroes had to be made extra-heroic in order to pass muster. War, and the memory and celebration of war, kept the Russian eye focused away from contemporary life, from the daily grind of the Brezhnev era. As Peter Vail argues:

Russian life in peacetime was fairly impoverished and never very fun. That's why during wartime, when these conditions seemed less important, a certain unity, a kind of trench brotherhood, a clarity of ideas, emerged: here's the enemy, here's the friend, and all contradictions disappeared. And for that reason war was endowed with a particular purity and beauty. War was presented as a cleansing flame, and to speak about it with a grin was unseemly. ${ }^{54}$

52 Tumarkin discusses the Grekov Military Art Studio and the 3-D panorama paintings of the Central Armed Forces Museum; the halls she describes were transferred intact to the new Museum of the Great Patriotic War, which opened in 1995. See Pamiat'o podvige, Moscow 1985, which Tumarkin cites, and compare it to the guidebook of the new Moscow museum.

Vail', "Geroi vremeni." 
No humor, only elevated words. Not life, but podvig. Even when war was not raging, a cult of war could keep that "pure," "cleansed" feeling of unity alive. If Khrushchev's thaw occurred during the hardening of the Cold War, then Brezhnev's cultural chill happened even as he explored detente and arms control with the United States. By 1974, ten years after Brezhnev took control of the Soviet Union, Nekrasov was in Paris, Solzhenitsyn was in Switzerland on his way to Vermont, and Alexander Tvardovsky was dead..$^{55}$ Six years later, Voinovich left for West Germany.

55 When he was offered his Writers' Union membership back a decade later, Voinovich only laughed. See Vladimir Voinovich and Michael Henry Heim, "An Exile's Dilemma," The Wilson Quarterly, 14.4 (Autumn 1990): 114-120. 